\title{
ANALISIS CLUSTER TERHADAP SPEKTRA INFRAMERAH FENOL, POLIEUGENOL DAN INTERAKSI KEDUANYA SEBUAH TINJAUAN STATISTIK
}

\author{
Agung Abadi Kiswandono \\ Fakultas Kesehatan Masyarakat, Universitas Prima Indonesia \\ Medan Sumatera Utara, Indonesia \\ e-mail :nau_shila@yahoo.com
}

\author{
ABSTRACT \\ Cluster Analisysis of Phenol Infrared Spectra, Poliugenol and Both \\ Interction Overview Statistics
}

\begin{abstract}
Identification had been carried out for eight different compounds using infrared spectrophotometer are phenol, polieugenol, and the mole ratio of phenol and polieugenol, and the results were analyzed using cluster analysis. The purpose of this study was to obtain infrared absorption on the interaction of these compounds, determine their group based on infrared absorption spectra and determine the characteristics of the resulting cluster. The results showed that the cluster analysis on the basis of infrared spectra could be grouped into three clusters, cluster compounds that had moderate absorption, low absorption and high absorption.
\end{abstract}

Keyword: cluster, polyeugenol, phenol

\begin{abstract}
ABSTRAK
Delapan jenis senyawa telah diidentifikasi menggunakan spektrofotometer inframerah, yaitu fenol, polieugenol dan perbandingan mol fenol dan polieugenol, lalu hasil identifikasi tersebut dilakukan analisis menggunakan analisis cluster untuk memperoleh hubungan interaksi serapan inframerah pada senyawa - senyawa tersebut, kemudian mengelompokkan jenis senyawa - senyawa tersebut berdasarkan serapan spektra inframerah serta mengetahui ciri - ciri cluster yang dihasilkan. Berdasarkan jenis serapan spektra inframerah, hasil analisis cluster dari delapan jenis senyawa dapat dikelompokkan menjadi tiga cluster, yaitu cluster senyawa yang mempunyai serapan sedang, cluster senyawa yang memiliki serapan rendah dan cluster senyawa yang memiliki serapan tinggi.
\end{abstract}

Kata kunci : cluster, polieugenol, fenol

\section{PENDAHULUAN}

Interaksi suatu senyawa dengan senyawa lainnya secara kualitatif dapat diketahui dengan spektra inframerah, karena spektra inframerah merupakan kekhasan sebuah molekul secara menyeluruh. Gugus - gugus atom tertentu memberikan penambahan serapan pada kerapatan tertentu (Silverstein, et.al. 1984) Spektrometri inframerah melingkupi pengamatan terhadap gerakan - gerakan atom di dalam molekul yang berupa vibrasi dan rotasi. Saat terjadi interaksi dengan radiasi inframerah, molekul dapat menyerap energi radiasi tersebut pada panjang gelombang yang spesifik sehingga terjadi transisi di antara tingkat vibrasi dasar (ground state) dan tingkat energi tereksitasi (excited state).

Keberagaman vibrasi yang terjadi secara simultan menghasilkan spektrum absorbsi yang sangat kompleks yang merupakan ciri khas dari gugus fungsi yang menyusun molekul dan keseluruhan konfigurasi molekul (Lambert et.al. 2001). Spektrum inframerah dari suatu senyawa pada dasarnya merupakan superposisi pita 
absorbsi dari gugus - gugus fungsi yang spesifik. Untuk analisis kualitatif, salah satu ciri spektrum inframerah adalah deteksi terhadap ada atau tidaknya absorbsi pada daerah-daerah frekuensi yang spesifik yang dapat dihubungkan dengan gerakan vibrasi stretching (ulur) dan bending (tekuk) yang spesifik pula. Data yang diperoleh dari spektra ini, dapat dibandingkan dengan spektra senyawa murni (standar) atau dari literatur sehingga dapat dilakukan identifikasi.

Pada suatu analisis spektrum inframerah, akan diperoleh banyak bilangan - bilangan gelombang, sesuai dengan senyawa - senyawa yang dianalisis. Serapan bilangan gelombang tersebut dapat diklasifikasikan atau dikelompokkan. Menurut analisis statistik, kriteria spektrum inframerah tersebut dinyatakan sebagai variat. Semakin banyak serapan dan peak yang menjadi kriteria suatu gugus fungsi ataupun atom tertentu akan semakin rumit analisis statistik yang harus dilakukan.

Analisis multivariat merupakan analisis yang cocok untuk meringkas data dengan peubah yang banyak. Beberapa analisis dalam analisis multivariat yang dapat digunakan untuk memahami dan mempermudah interpretasi data multivariat diantaranya adalah analisis Cluster (Fraley dan Raftery, 2007, Oh dan Raftery, 2007), bahkan Rafteri dan Dean (2006) telah membuat suatu model-based clustering. Model yang dibuat ini lebih konsisten dan lebih akurat hasilnya dalam mengestimasi jumlah kelompok dengan rata - rata kesalahan yang rendah.

Analisis cluster merupakan teknik multivariat dengan tujuan utama untuk mengelompokkan obyek - obyek berdasarkan karakteristik yang dimilikinya. Analisis cluster sangat berguna untuk menganalisis dan meringkas informasi yang memiliki banyak data (Fraley et/al. 2005). Analisis cluster mengklasifikasi obyek sehingga setiap obyek yang paling dekat kesamaannya dengan obyek lain berada dalam cluster yang sama. Clustercluster yang terbentuk memiliki homogenitas internal yang tinggi dan heterogenitas eksternal yang tinggi
(Kuncoro, 2003). Obyek dalam setiap kelompok cenderung mirip satu sama lain dan berbeda jauh (tidak sama) dengan obyek dari cluster lainnya. Proses analisis cluster dapat dijelaskan dalam empat tahap, yaitu (1) Perumusan Masalah berdasarkan tujuannya (2) Menentukan ukuran ketidakmiripan (3) Memilih prosedur cluster (4) Interpretasi dan pemberian nama terhadap Cluster (Supranto, 2000).

Beberapa penelitian telah memakai "analisis cluster" sebagai alat bantu untuk melihat hubungan dan mengelompokan obyek penelitian (Purwaningsih, 2007, Udiyani, 2007, dan Budhi et.al. 2008) tetapi belum ada peneliti menggunakan analisis cluster untuk menganalsis spektrum inframerah. Serapan inframerah pada beberapa senyawa, misalnya fenol, polieugenol dan interaksi keduanya memiliki banyak variat, yakni berupa peak yang dinyatakan sebagai bilangan bilangan gelombang, sehingga data - data ini dapat dikelompokkan dan dianalisis menggunakan analisis cluster. Tulisan ini mencoba untuk membahas mengenai analisis cluster terhadap spektrum inframerah fenol, polieugenol dan interaksi keduanya. Untuk melihat interaksi fenol polieugenol pada penelitian ini dibuat dengan mencampurkan larutan fenol dengan polieugenol dalam pelarut kloroform melalui proses ekstraksi (shaker) dengan beberapa perbandingan mol.

\section{BAHAN DAN METODE}

\section{Bahan dan Alat}

Bahan yang dipakai pada penelitian ini adalah fenol, kloroform, akuabides dan polieugenol, sedangkan alat yang digunakan adalah corong pisah, alat penunjang berupa alat-alat gelas dan botol, neraca analitik (Mettler Toledo AB54-S), shaker, desikator, spektrofotometer inframerah (Shimadzu FT-IR 8201PC) dan program Minitab 14. 


\section{Metode Penelitian}

\section{Spektrum Inframerah 2010)}

(Kiswandono,

Larutan fenol dan polieugenol dengan perbandingan mol $50: 1,20: 1$, $1: 1,1: 2,1: 15$ dan $1: 47$ dimasukkan dalam botol, kemudian dishaker selama 72 jam, lalu dipisahkan antara fasa organik dengan fasa air. Fasa organik diuapkan dan padatan yang diperoleh dikeringkan dalam desikator untuk kemudian dianalisis dengan spektrofotometer Inframerah.

\section{Prosedur Analisis Cluster (Purwaningsih, 2007)}

Langkah - langkah yang akan dilakukan dalam menentukan analisis cluster adalah sebagai berikut :

a. Merumuskan masalah

b. Menentukan ukuran ketakmiripan antar dua obyek, dalam hal ini dihitung menggunakan jarak Euclidean dan Pearson.

c. Membuat cluster, proses cluster ini dilakukan dengan dua metode yaitu secara hirarki dan non hirarki.

d. Memberi nama spesifik setelah cluster terbentuk, untuk menggambarkan isi cluster tersebut.

e. Membuat kesimpulan

\section{Analisis Cluster dengan Minitab 14 (Udiyani, 2007)}

Untuk mempercepat dan mendapatkan hasil dengan akurat, maka proses data menggunakan program Minitab 14. Obyek dikombinasikan berdasarkan jarak atau kesamaan masing - masing bilangan gelombang. Penggerombolan aglomeratif yang sering digunakan dimulai dengan satu obyek dan menggabungkannya ke kelompok obyek yang lebih besar.

Langkah pertama adalah menghitung matriks jarak keseluruhan data dengan salah satu ukuran jarak
(Perhitungan ini digunakan untuk semua obyek, Jarak antara satu dan obyek yang sama adalah 0).

$$
\begin{aligned}
\mathrm{d}_{12}= & {\left[\left(x_{11}-x_{21}\right)^{2}+\left(x_{12}-x_{22}\right)^{2} \ldots . .+\left(x_{115}-\right.\right.} \\
& \left.\left.x_{215}\right)^{2}\right]^{1 / 2} \ldots \ldots \ldots \ldots \ldots \ldots \ldots \ldots \ldots \ldots \ldots \ldots \ldots \ldots
\end{aligned}
$$

Setelah terentuk satu cluster, lalu proses Agromerasi dimulai dengan jarak antar obyek yang paling dekat.

Langkah ke dua, adalah setelah terbentuknya cluster maka akan terlihat nilai koefisien dan nilai inilah yang menunjukkan jarak terdekat antara dua obyek tersebut.

\section{HASIL DAN PEMBAHASAN}

\section{Spektra inframerah dan Intensitas Serapan}

Spektrum inframerah dari kedelapan sampel seperti terlihat pada Gambar 1, kemudian jenis serapan spektrum inframerah dan besarnya intensitas dari ke delapan sampel secara lengkap disajikan pada Tabel 1 .

Spektra inframerah merekam panjang gelombang atau frekuensi versus $\%$ T. Bila suatu senyawa menyerap cahaya pada suatu panjang gelombang tertentu, maka intensitas cahaya yang diteruskan oleh cuplikan akan berkurang, hal ini mengakibatkan penurunan $\% \mathrm{~T}$ dan dalam spektra terlihat sebagai puncak serapan. Bagian spektra dengan \% T menunjukkan angka 100 atau mendekati 100 , berarti tidak ada serapan untuk suatu senyawa pada panjang gelombang tersebut.

Agar tidak terjadi salah interprestasi, kemudian \% $\mathrm{T}$ dikonversi menjadi absorbansi, kemudian data serapan inframerah dalam bentuk absorbansi ini digunakan sebagai data untuk analisis Cluster. Data tersebut seperti terlihat pada Tabel 2 dan 3. Data yang digunakan dalam makalah ini diambil dari delapan senyawa pada Tabel 1,2 dan 3, Pada Tabel tersebut terdapat 15 variabel, dimana variabel - variabel tersebut adalah jenis serapan inframerah. 
Tabel 1. Intensitas serapan (\%T ) pada FT-IR untul fenol, polieugenol dan fenol : polieugenol (Yogyakarta, 2010)

\begin{tabular}{|c|c|c|c|c|c|c|c|c|c|c|c|c|c|c|c|}
\hline \multirow{4}{*}{ Senyama } & \multicolumn{15}{|c|}{ Intensitas serapan (\% } \\
\hline & $-\mathrm{OH}$ & $\begin{array}{c}\text { C-H } \\
\text { teluakan } \\
\text { (alkenil) }\end{array}$ & \multicolumn{2}{|c|}{$\begin{array}{l}\text { C.H } \\
\text { telukan } \\
\text { (allit) }\end{array}$} & \multicolumn{3}{|c|}{$\mathrm{C}=\mathrm{C}$ aromatik } & $\begin{array}{c}\text { O-H } \\
\text { dalam } \\
\text { bidang }\end{array}$ & $\begin{array}{c}\text { Tluran } \\
\text { C-H }\end{array}$ & \multicolumn{2}{|c|}{$\mathrm{C}-0$ eter } & \multicolumn{2}{|c|}{$\begin{array}{c}\text { C-H kelaur } \\
\text { bidnng }\end{array}$} & $\begin{array}{l}\mathrm{C}=\mathrm{C} \\
\text { keluar } \\
\text { bidang }\end{array}$ & $\begin{array}{c}0 \text {-H } \\
\text { keluar } \\
\text { bidang }\end{array}$ \\
\hline & 3340,7 & $\begin{array}{l}3047- \\
3093\end{array}$ & \multicolumn{2}{|c|}{$2962-2846$} & \multicolumn{3}{|c|}{$1473: 1496 ; 1597$} & 1365 & 1226 & \multicolumn{2}{|c|}{$1273 ; 1033$} & \multicolumn{2}{|c|}{$810 ; 756$} & 686 & 509 \\
\hline & 1 & 2 & 3 & 4 & 5 & 6 & 7 & 8 & 9 & 10 & 11 & 12 & 13 & 14 & 15 \\
\hline Fenol & 1298 & 17,48 & 28,25 & 32.98 & 14,95 & 14,96 & 13,16 & 15,64 & 14,40 & 100,00 & 100,90 & 15,85 & 18,90 & 16,7 & 8,90 \\
\hline Polieugenol & 30,37 & 100,90 & 28,77 & $32,+6$ & 27,90 & 25,69 & 32,98 & 32,37 & 27,67 & 26,06 & 3190 & 41,20 & 37,19 & 100,00 & 38,25 \\
\hline $\begin{array}{l}\text { Fenol: Polieugenol } \\
(\mathbf{5 0}: 1) \\
\text { Fenol: Polieugenol } \\
(20: 1)\end{array}$ & 21,77 & 40,13 & 31,98 & 32,03 & 23,22 & 21,12 & 21,30 & 33,31 & 1652 & 22.84 & 4238 & 17,63 & $37,+2$ & 33,21 & 37,52 \\
\hline $\begin{array}{l}\text { Fenol: Poliengenol } \\
(1: 1) \\
\text { Fenol: Poliengenol }\end{array}$ & 3,84 & 11,45 & 355 & 12,37 & 2,79 & 2,16 & 4,55 & 6,14 & 2.06 & 204 & 8,30 & 2,02 & 14,39 & 18,26 & 17,21 \\
\hline $\begin{array}{l}(1: 2) \\
\text { Fenol: Poliengenol } \\
(1: 15) \\
\text { Fenol: Poliengenol }\end{array}$ & 15,24 & 41,31 & 29,68 & 41,26 & $23, \$ 1$ & 17,90 & 36,37 & 35,86 & 18,78 & 17,23 & 36,97 & 13,88 & 44,83 & 49,37 & 100,00 \\
\hline$(1: 4)$ & 33,75 & 100.90 & 14,61 & 1695 & 16,94 & 16,75 & 17,30 & 18,27 & 16,70 & 16,39 & 18,63 & 19,01 & $22: 55$ & 23.82 & 100,00 \\
\hline
\end{tabular}

Tabel 2. Intensitas serapan ( $\% \mathrm{~T}$ ) pada FT-IR untul fenol, polieugenol dan fenolpolieugenol (Yogyakarta, 2010)

\begin{tabular}{|c|c|c|c|c|c|c|c|c|c|c|c|c|c|c|c|}
\hline \multirow{2}{*}{ Senyawa } & \multicolumn{15}{|c|}{ Intensitas serapan $(\mathrm{T})$} \\
\hline & 1 & 2 & 3 & 4 & 5 & 6 & 7 & 8 & 9 & 10 & 11 & 12 & 13 & 14 & 15 \\
\hline Fenol & 0,13 & 0,17 & 0,28 & 0,33 & 0,15 & 0,15 & 0,13 & 0,16 & 0,14 & 1,00 & 1,00 & 0,16 & 0,19 & 0,17 & 0,08 \\
\hline $\begin{array}{l}\text { Polieugenol } \\
\text { Fenol: Polieugenol }\end{array}$ & 0,30 & 1,00 & 0,29 & 0,32 & 0,28 & 0,26 & 0,33 & 0,32 & 0,28 & 0,26 & 0,32 & 0,41 & 0,37 & 1,00 & 0,38 \\
\hline & 0,22 & 0,40 & 0,32 & 0,32 & 0,23 & 0,21 & 0,21 & 0,33 & 0,17 & 0,23 & 0,42 & 0,18 & 0,37 & 0,33 & 0,38 \\
\hline $\begin{array}{l}\text { (20:1) } \\
\text { Fenol: Polieugenol }\end{array}$ & 0,19 & 0,32 & 0,31 & 0,38 & 0,23 & 0,23 & 0,22 & 0,32 & 0,21 & 1,00 & 0,45 & 0,26 & 0,36 & 0,33 & 0,37 \\
\hline $\begin{array}{l}(1: 1) \\
\text { Fenol: Polieugenol }\end{array}$ & 0,04 & 0,11 & 0,04 & 0,12 & 0,03 & 0,02 & 0,05 & 0,06 & 0,02 & 0,02 & 0,08 & 0,02 & 0,14 & 0,18 & 0,17 \\
\hline $\begin{array}{l}(1: 2) \\
\text { Fenol: Polieuge }\end{array}$ & 0,22 & 0,36 & 0,19 & 0,36 & 0,13 & 0,08 & 0,21 & 0,25 & 0,08 & 0,08 & 0,29 & 0,05 & 0,38 & 0,41 & 0,38 \\
\hline $\begin{array}{l}(1: 15) \\
\text { Fenol: Polieug }\end{array}$ & 0,15 & 0,41 & 0,30 & 0,41 & 0,24 & 0,17 & 0,36 & 0,36 & 0,19 & 0,17 & 0,36 & 0,14 & 0,45 & 0,49 & 1,00 \\
\hline & 0,34 & 1,00 & 0,15 & 0,17 & 0,17 & 0,17 & 0,17 & 0,18 & 0,17 & 0,16 & 0,19 & 0,19 & 0,23 & 0,24 & 1,00 \\
\hline
\end{tabular}


Tabel 3. Absorbansi serapan $(A=-\log T)$ pada FT-IR untul fenol, polieugenol dan fenolpolieugenol (Yogyakarta, 2010)

\begin{tabular}{|c|c|c|c|c|c|c|c|c|c|c|c|c|c|c|c|}
\hline \multirow{2}{*}{ Sengani } & \multicolumn{15}{|c|}{ Intensitzs serapan $(A=-\operatorname{lgg} T)$} \\
\hline & 1 & ? & 3 & 4 & $\vdots$ & 6 & 7 & 8 & 9 & 10 & 11 & 1: & 13 & 14 & 15 \\
\hline Fenel & 0,99 & 0,6 & 0,5 & 0,48 & 0.83 & 0.83 & 038 & 0,81 & 0.S4 & 0.90 & 0.90 & 0.80 & 0,7 & 0,78 & 1,10 \\
\hline Polievgenend & 6:5: & 9,00 & 0.54 & 0,49 & 0,5 & $0 ; 9$ & 0,48 & 0,49 & $0 ; 6$ & $0 \$ 8$ & 630 & 0,39 & 0,43 & 0,90 & Q, 4 ? \\
\hline $\begin{array}{l}\text { Fend: Polieugenal } \\
(\mathbf{5 0 : 1 )}\end{array}$ & 0.66 & 0,0 & 0,50 & 0,49 & 0,63 & 0,68 & 0,67 & 0,48 & 0,78 & 0,64 & 0.37? & 0,7 & 0,43 & 1,48 & 0,43 \\
\hline $\begin{array}{l}\text { Fenal: Poliengenol } \\
(20: 1) \\
\text { Fenal:Poliegęenol }\end{array}$ & 0,73 & 0,19 & 0,5] & d, 4 ? & 0.64 & 0,63 & 0.66 & $0 ; 0$ & 0,68 & 0,00 & 035 & 0.99 & D,At & 0,18 & 0,43 \\
\hline $\begin{array}{l}\text { (1:1) } \\
\text { Fenal: Poliegenol }\end{array}$ & 1,: & 694 & 1,15 & 091 & I:3 & $160^{\circ}$ & 134 & 1.1 & 169 & 1,69 & 1998 & 169 & 6.84 & 0,7 & $0, \%$ \\
\hline$(1: 2)$ & 0,66 & $0,4+4$ & 0,7 & 0,15 & 0,98 & $1,1,18$ & 0,58 & 0,50 & 1111 & 1,11 & 0,54 & 127 & 0,4: & 0.99 & $0,1 ?$ \\
\hline $\begin{array}{l}\text { Fenal: Politugenol } \\
(1: 15)\end{array}$ & 0.8? & 038 & $0 \$ 3$ & 1,38 & 0,62 & 0,77 & 0,4 & 0,45 & 0,73 & 0,6 & 0,44 & 0.86 & 0,35 & 031 & 0.00 \\
\hline $\begin{array}{l}\text { Fesol: Poliegenenol } \\
(1: 4)\end{array}$ & $0,4^{*}$ & 0.00 & 0.84 & 0.7 & 0.77 & 0,78 & 0,6 & 0,4 & 0.78 & 0.9 & 0,3 & 0.72 & 0.65 & $0,6 ?$ & 0.000 \\
\hline
\end{tabular}

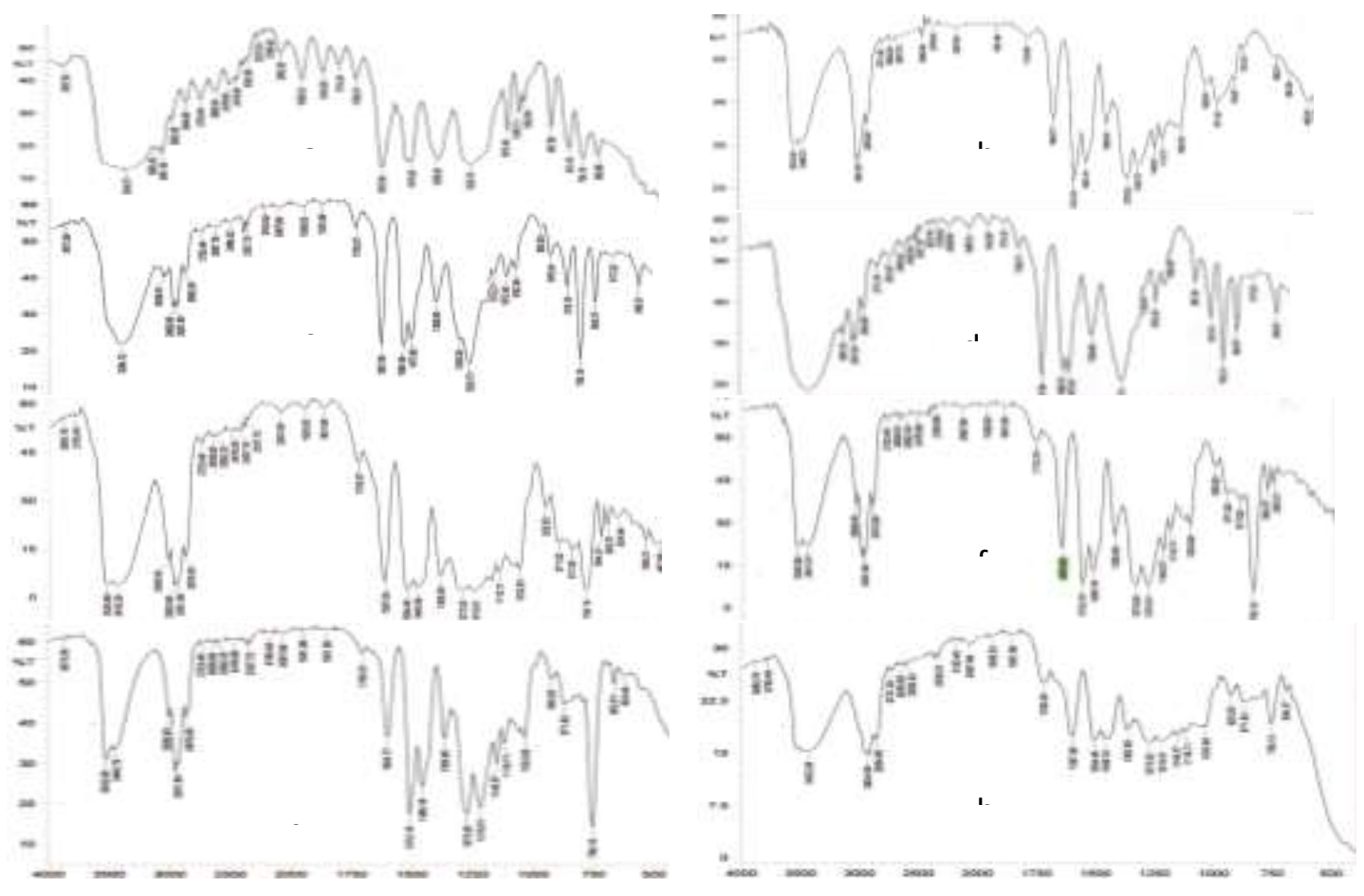

Gambar 1. Spektra IR (a). Fenol, (b). Polieugenol, perbandingan mol fenol : polieugenol (c) $50: 1$ (d) $20: 1$ (e) $1: 1$ (f) $1: 2$ (g) $1: 15$ (h) $1: 47$. 
Ada dua proses penting yaitu algoritma cluster dalam pembentukan cluster dan menentukan jumlah cluster yang akan dibentuk. Keduanya mempunyai implikasi substansial tidak hanya pada hasil yang diperoleh tetapi juga pada interpretasi yang akan dilakukan terhadap hasil tersebut. Dua metode paling umum dalam algoritma cluster adalah metode hirarkhi dan metode non hirarkhi.

\section{Proses clustering secara hirarki}

Proses clustering dilakukan secara hirarki dan non-hirarki, kedua metode tersebut digunakan secara berdampingan. Pada makalah ini proses clustering secara hirarki menggunakan dua metode, yakni eucledian dan pearson secara single linkage, average linkage dan median linkage, sedangkan proses clustering secara non-hirarki menggunakan metode k-means. Proses komputasi yang digunakan untuk mengolah data adalah program minitab 14.
Obyek dikombinasikan berdasar kan jarak atau kesamaan masing masing bilangan gelombang. Penggerombolan aglomeratif yang sering digunakan dimulai dengan satu obyek dan menggabungkan nya ke kelompok obyek yang lebih besar. Proses penggabungan dua objek atau lebih dapat dilihat pada tabel Agglomeration Schedule (Tabel 4).

Langkah pertama adalah menghitung matriks jarak keseluruhan data dengan salah satu ukuran jarak. Angka 1,761 diperoleh dengan menggunakan formula 1 .

$$
\begin{aligned}
\mathrm{d}_{12}= & {\left[(0,89-0,52)^{2}+(0,76-0,00)^{2}+\right.} \\
& (0,55-0,54)^{2}+\ldots+(1,10- \\
& \left.0,42)^{2}\right]^{1 / 2} \\
\mathrm{~d}_{12}= & 1,761 .
\end{aligned}
$$

Perhitungan untuk obyek lain nya dianalogikan seperti perhitungan tersebut di atas. Jarak antara satu dan obyek yang sama adalah 0 .

Tabel 4. Hasil Perhitungan Matriks Jarak Tahap Pertama (Yogyakarta, 2010)

\begin{tabular}{ccccccccc}
\hline & 1 & 2 & 3 & 4 & 5 & 6 & 7 & 8 \\
\hline 1 & 0 & 1,761 & 1,255 & 1,065 & 2,928 & 1,690 & 1,699 & 1,832 \\
2 & 1,761 & 0 & 0,813 & 0,988 & 3,390 & 1,470 & 0,923 & 1,122 \\
3 & 1,255 & 0,813 & 0 & 0,683 & 2,902 & 0,962 & $\mathbf{0 , 5 9 6}$ & 0,949 \\
4 & 1,065 & 0,988 & 0,683 & 0 & 3,261 & 1,499 & 0,988 & 1,300 \\
5 & 2,928 & 3,390 & 2,902 & 3,261 & 0 & 2,175 & 2,958 & 2,732 \\
6 & 1,690 & 1,470 & 0,962 & 1,499 & 2,175 & 0 & 0,973 & 1,143 \\
7 & 1,699 & 0,923 & $\mathbf{0 , 5 9 6}$ & 0,988 & 2,958 & 0,973 & 0 & 1,009 \\
8 & 1,832 & 1,122 & 0,949 & 1,300 & 2,732 & 1,143 & 1,009 & 0 \\
\hline
\end{tabular}


Tabel 5. Hasil Perhitungan Matriks Jarak Tahap Kedua (Yogyakarta, 2010)

\begin{tabular}{|c|c|c|c|c|c|c|c|}
\hline & 1 & 2 & $3 \& 7$ & 4 & 5 & 6 & 8 \\
\hline 1 & 0.000 & 1.287 & 1.034 & 1.026 & 3.159 & 1.580 & 1.311 \\
\hline 2 & 1.287 & 0 & 0.406 & 0.836 & 3.146 & 1.216 & 0.759 \\
\hline $3 \& 7$ & 1.034 & 0.406 & 0 & 0.342 & 3.081 & 1.231 & 0.792 \\
\hline 4 & 1.026 & 0.836 & 0.342 & 0 & 1.630 & 1.837 & 1.973 \\
\hline 5 & 3.159 & 3.146 & 3.081 & 1.630 & 0 & 1.088 & 1.966 \\
\hline 6 & 1.580 & 1.216 & 1.231 & 1.837 & 1.088 & 0 & 0.486 \\
\hline 8 & 1.311 & 0.759 & 0.792 & 1.973 & 1.966 & 0.486 & 0 \\
\hline
\end{tabular}

Keterangan : angka pada kolom dan baris satu merupakan jenis senyawa
1. Fenol
4. Fenol : Polieugenol $20: 1$
7. Fenol : Polieugenol $1: 15$
2. Polieugenol
5. Fenol : Polieugenol $1: 1$
8. Fenol : Polieugenol $1: 47$
3. Fenol : Polieugenol $50: 1$
6. Fenol : Polieugenol $1: 2$

Pada tahap pertama, terbentuk satu cluster antara senyawa 7 dengan senyawa 3, dengan nilai koefisien sebesar 0,596 yang menunjukkan besarnya jarak antara senyawa 7 dan senyawa 3 . Proses Agglomerasi dimulai dengan jarak antar obyek yang paling dekat, yaitu jarak antara senyawa 7 dan senyawa 3 yang memiliki jarak terdekat dari 28 kombinasi jarak antar obyek yang ada. Pada tahap kedua, dapat dilihat terbentuknya cluster antara senyawa 3,7 dengan senyawa 4, dengan nilai koefisien sebesar 0,342 yang menunjukkan besarnya jarak terdekat antara senyawa 3,7 dengan senyawa 4 , seperti yang terlihat pada Tabel 5 .

Proses cluster dilanjutkan hingga pada kolom tahap selanjutnya menunjuk kan nilai tahap 0 , yang berarti proses cluster berhenti. Secara komputasi proses cluster dapat dikerjakan lebih cepat dengan memasukkan data pada program minitab 14, sehingga akan diperoleh dendogram seperti pada Gambar 2.

Gambaran secara visual dari hasil analsis cluster ini disajikan pada dendogramnya. Untuk menentukan jumlah cluster yang terbaik belum ada metode pasti yang bisa digunakan, sehingga untuk menentukan jumlah cluster dari dendogram dilihat dari jarak terpanjang pada dendogram saat pembentukan clusternya. Jika sulit melihat secara visual, dapat dilihat dari jarak pembentukan antar cluster yaitu level jarak iterasi ke-i dikurangi level jarak iterasi ke - $(i-1)$.

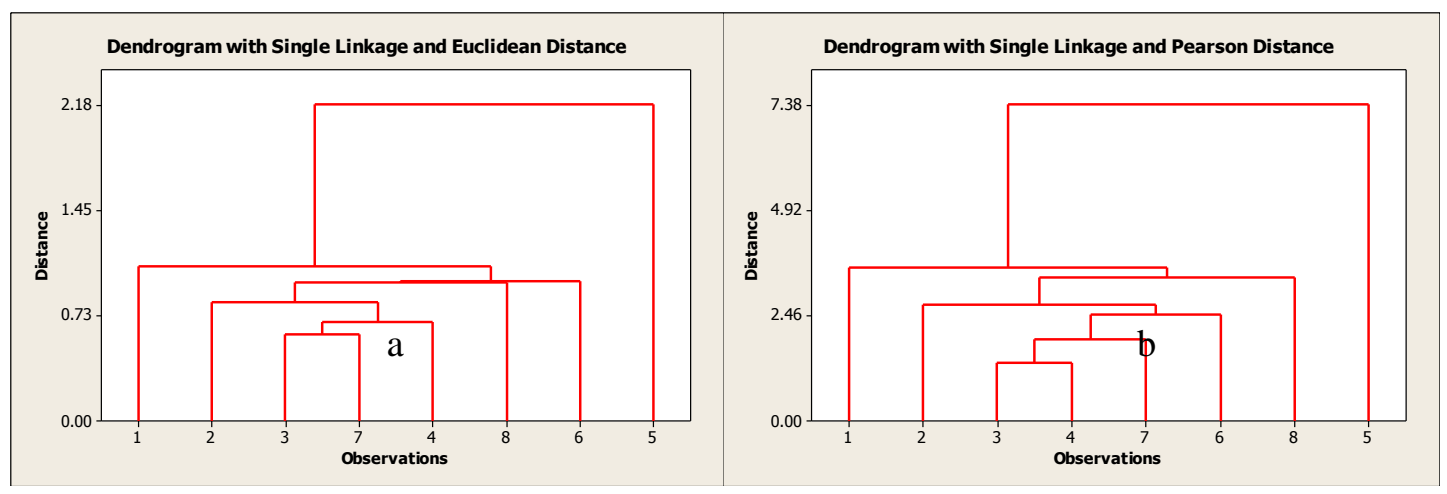

Gambar 2. Dendogram dengan Single Linkage (a) Euclidean distance (b) Pearson Distance 
Tabel 6. Jarak Pembentukan Terbesar Menjadi Satu Cluster (Yogyakarta, 2010)

\begin{tabular}{ccccc}
\hline \multicolumn{5}{c}{ Single Linkage } \\
\hline Iterasi & $\begin{array}{c}\text { Juml cluster } \\
\text { terbentuk }\end{array}$ & Level Kesamaan & Level Jarak & $\begin{array}{c}\text { Jarak Pembentukan } \\
\text { Antar cluster }\end{array}$ \\
\hline 2 & 6 & 79,8432 & 0,68323 & 0,08733 \\
3 & 5 & 76,0159 & 0,81296 & 0,12973 \\
4 & 4 & 71,9915 & 0,94937 & 0,13641 \\
5 & 3 & 71,6103 & 0,96229 & 0,01292 \\
6 & 2 & 68,586 & 1,0648 & 0,10251 \\
7 & 1 & 35,8226 & 2,17534 & 1,11054 \\
\hline
\end{tabular}

Pada Tabel 6 terlihat bahwa jarak pembentukan terbesar terjadi pada saat pembentukan menjadi satu cluster, dengan nilai 1,11054 Sehingga kesimpulan yang dapat diambil dari dendogram di atas adalah bahwa cluster terbentuk yang dipilih adalah satu cluster (seluruh pengamatan).

\section{Proses clustering non-hirarki}

Metode non-hirarki memproses semua obyek (kasus) secara sekaligus. Metode non-hirarki yang digunakan adalah $k$-means dimana $\mathrm{k}$ adalah banyaknya cluster $=3$. Nilai 3 diambil dari 3 cluster terakhir yang terjadi, yaitu pada metode Pearson terdapat pada senyawa 1, 5 dan 8 sehingga pada metode non-hirarki ini banyaknya cluster adalah 3. Proses pengclusteran dengan metode $k$-means adalah :

a) Besarnya k (banyaknya cluster) $=3$.

b) Centroid ada 3 karena jumlah cluster ada tiga. Nilai centroid diperoleh secara acak (dalam hal ini diambil dari 3 cluster terakhir yang sering muncul), yaitu senyawa $1,6,5$ untuk metode eucledian dan 1, 8, 5 untuk metode Pearson.
$\mathrm{C}_{1}$ (centroid cluster 1) adalah nilai ke15 variabel dari senyawa 1 .

$\mathrm{C}_{2}$ (centroid cluster 2) adalah nilai ke15 variabel dari senyawa 5 .

$\mathrm{C}_{3}$ (centroid cluster 3) adalah nilai ke15 variabel dari senyawa 8 .

Jarak setiap obyek dari centroid (pusat cluster) pertama dengan menggunakan kuadrat jarak euclidean pada Tabel 7 adalah sebagai berikut :

Senyawa $1 ; \mathrm{C}-1$ $\left[(0,89-0,89)^{2}+(0,76-0,76)^{2}+(0,55-\right.$ $\left.0,55)^{2}+\ldots .+(1,1-1,1)^{2}\right]=0$

Senyawa $2 ; \mathrm{C}-1$ $\left[(0,52-0,89)^{2}+(0-0,76)^{2}+(0,54-\right.$ $\left.0,55)^{2}+\ldots .+(0,42-1,1)^{2}\right]=3,1$

Senyawa $1 ; \mathrm{C}-2$ :

$\left[(0,89-1,42)^{2}+(0,76-0,94)^{2}+(0,55-\right.$ $\left.1,45)^{2}+\ldots .+(1,1-0,76)^{2}\right]=8,57$

Untuk senyawa yang lain dihitung dengan cara yang sama, sehingga didapat kan data seperti Tabel 8 dan 9 . 
c) Selanjutnya menghitung kembali centroid yang baru, yang merupakan rataan ke - 15 variabel pada setiap cluster (Tabel 10).

$\mathrm{C}_{1}^{*}$ (centroid cluster 1) adalah nilai ke - 15 variabel dari 2 senyawa yang masuk ke dalam cluster 1 pada langkah $b$.

$\mathrm{C}_{2}^{*}$ (centroid cluster 2) adalah nilai rata - rata ke -15 variabel dari 1 senyawa yang masuk ke cluster 2 pada langkah b.

$\mathrm{C}_{3}^{*}$ (centroid cluster 3 ) adalah nilai rata - rata ke - 15 variabel dari 5 senyawa yang masuk ke cluster 3 pada langkah $b$.
Kemudian jarak setiap obyek dari centroid (pusat cluster) pertama dengan menggunakan kuadrat jarak euclidean seperti langkah b di atas diperoleh data seperti Tabel 11 dan 12.

Karena tidak ada perubahan dari hasil pengclusteran, yakni hasilnya sama dengan langkah b, maka proses berhenti, sehingga dari tiga cluster yang terbentuk di dapatkan rata - rata besarnya serapan (dalam satuan absorbansi) pada setiap cluster, seperti dalam Tabel 13.

Artinya, untuk serapan gugus $\mathrm{OH}$ (pada kolom 1) terbesar berada pada cluster ketiga dengan rata - rata sebesar 0,63, sedangkan serapan $\mathrm{OH}$ terkecil pada cluster kedua dengan rata-rata sebesar 0,28 dan seterusnya.

Tabel 7. Nilai Centroid dari tiap Cluster (Yogyakarta, 2010)

\begin{tabular}{cccccccccccccccc}
\hline $\mathbf{1}$ & 0.89 & 0.76 & 0.55 & 0.48 & 0.83 & 0.83 & 0.88 & 0.81 & 0.84 & 0 & 0 & 0.8 & 0.72 & 0.78 & 1.1 \\
\hline $\mathbf{5}$ & 1.42 & 0.94 & 1.45 & 0.91 & 1.55 & 1.67 & 1.34 & 1.21 & 1.69 & 1.69 & 1.08 & 1.69 & 0.84 & 0.74 & 0.76 \\
$\mathbf{8}$ & 0.47 & 0 & 0.84 & 0.77 & 0.77 & 0.78 & 0.76 & 0.74 & 0.78 & 0.79 & 0.73 & 0.72 & 0.65 & 0.62 & 0 \\
\hline
\end{tabular}

Tabel 8. Hasil Perhitungan Jarak Setiap Obyek dengan Menggunakan Kuadrat Jarak Euclidean

\begin{tabular}{|c|c|c|c|}
\hline & C1 & C2 & C3 \\
\hline $\mathbf{1}$ & 0.00 & 8.57 & 3.36 \\
\hline $\mathbf{2}$ & 3.10 & 11.49 & 1.26 \\
\hline $\mathbf{3}$ & 1.58 & 8.42 & 0.90 \\
\hline $\mathbf{4}$ & 1.13 & 10.63 & 1.69 \\
\hline $\mathbf{5}$ & 8.57 & 0.00 & 7.47 \\
\hline $\mathbf{6}$ & 2.86 & 4.73 & 1.31 \\
\hline $\mathbf{7}$ & 2.89 & 8.75 & 1.02 \\
\hline $\mathbf{8}$ & 3.36 & 7.47 & 0.00 \\
\hline
\end{tabular}

Keterangan

a. Jarak terdekat senyawa 1 adalah dengan $\mathrm{C} 1$, sehingga senyawa 1 dikelompokkan dalam cluster 1

b. Jarak terdekat senyawa 2 adalah dengan C3, sehingga senyawa 2 dikelompokkan dalam cluster 3.

c. dan seterusnya, sehingga didapatkan kelompok senyawa pada cluster-nya masing masing, dari tabel tersebut (sebelah kanan) didapatkan cluster sebagai berikut, Cluster 1 dengan anggota senyawa 1 dan senyawa 4, Cluster 2 dengan anggota senyawa 5 dan Cluster 3 dengan anggota senyawa 2, 3, 6, 7 dan 8 
Tabel 10. Nilai Centroid dari tiap Cluster (Yogyakarta, 2010)

\begin{tabular}{llllllllllllllll}
\hline $\mathbf{1}$ & 0.81 & 0.63 & 0.53 & 0.45 & 0.74 & 0.73 & 0.77 & 0.66 & 0.76 & 0.00 & 0.18 & 0.70 & 0.58 & 0.63 & 0.77 \\
\hline $\mathbf{5}$ & 1.42 & 0.94 & 1.45 & 0.91 & 1.55 & 1.67 & 1.34 & 1.21 & 1.69 & 1.69 & 1.08 & 1.69 & 0.84 & 0.74 & 0.76 \\
& & & & & & & & & & & & & & & \\
$\mathbf{8}$ & 0.63 & 0.24 & 0.63 & 0.52 & 0.69 & 0.78 & 0.61 & 0.55 & 0.79 & 0.78 & 0.52 & 0.80 & 0.46 & 0.36 & 0.25 \\
\hline
\end{tabular}

Tabel 11. Hasil Perhitungan Jarak Setiap Obyek dengan Menggunakan Kuadrat Jarak Euclidean
Tabel 12. Hasil Pengelompokan Berdasarkan Cluster Terdekat

\begin{tabular}{cccc}
\hline & C1 & C2 & C3 \\
\hline $\mathbf{1}$ & 0.28 & 8.57 & 2.34 \\
$\mathbf{2}$ & 1.76 & 11.49 & 0.57 \\
$\mathbf{3}$ & 0.74 & 8.42 & 0.15 \\
$\mathbf{4}$ & 0.28 & 10.63 & 0.86 \\
$\mathbf{5}$ & 9.32 & 0.00 & 7.76 \\
$\mathbf{6}$ & 2.27 & 4.73 & 0.65 \\
$\mathbf{7}$ & 1.65 & 8.75 & 0.22 \\
$\mathbf{8}$ & 2.24 & 7.47 & 0.48 \\
\hline
\end{tabular}

\begin{tabular}{ccc}
\hline C1 & C2 & C3 \\
\hline 1 & & 2 \\
& & 3 \\
4 & & \\
& 5 & 6 \\
& & 7 \\
& & 8 \\
\hline
\end{tabular}

Keterangan

a. Jarak terdekat senyawa 1 adalah dengan C1, sehingga senyawa 1 dikelompokkan dalam cluster 1

b. Jarak terdekat senyawa 2 adalah dengan C3, sehingga senyawa 2 dikelompokkan dalam cluster 3

c. dan seterusnya, sehingga didapatkan kelompok senyawa pada cluster-nya masing masing, sehingga didapatkan 3 kelompok cluster, yaitu Cluster 1 dengan anggota senyawa 1 dan senyawa 4, Cluster 2 dengan anggota senyawa 5 dan Cluster 3 dengan anggota senyawa 2, 3, 6, 7 dan 8 .

Tabel 13. Nilai Rata - rata Serapan pada Setiap Cluster (Yogyakarta, 2010)

\begin{tabular}{cccccccccccccccc}
\hline & 1 & 2 & 3 & 4 & 5 & 6 & 7 & 8 & 9 & 10 & 11 & 12 & 13 & 14 & 15 \\
\hline C1 & 0.32 & 0.25 & 0.21 & 0.18 & 0.29 & 0.29 & 0.31 & 0.26 & 0.3 & 0 & 0.07 & 0.28 & 0.23 & 0.25 & 0.31 \\
C2 & 0.28 & 0.19 & 0.29 & 0.18 & 0.31 & 0.33 & 0.27 & 0.24 & 0.34 & 0.34 & 0.22 & 0.34 & 0.17 & 0.15 & 0.15 \\
C3 & 0.63 & 0.24 & 0.63 & 0.52 & 0.69 & 0.78 & 0.61 & 0.55 & 0.79 & 0.78 & 0.52 & 0.8 & 0.46 & 0.36 & 0.25 \\
\hline
\end{tabular}


Tabel 14. Klasifikasi Nama Cluster yang Terbentuk

\begin{tabular}{cccc}
\hline & $\begin{array}{c}\text { C1 } \\
\text { (sedang) }\end{array}$ & $\begin{array}{c}\text { C2 } \\
\text { (rendah) }\end{array}$ & $\begin{array}{c}\text { C3 } \\
\text { (Tinggi) }\end{array}$ \\
\hline 1 & 0.28 & & 0.57 \\
2 & & & 0.15 \\
3 & 0.28 & & \\
4 & & 0.00 & 0.65 \\
5 & & & 0.22 \\
6 & & & 0.48 \\
7 & & $\mathbf{0 . 0 0}$ & $\mathbf{0 . 4 2}$ \\
8 & $\mathbf{0 . 2 8}$ & & \\
\hline Rata $^{2}$ & & & \\
\hline
\end{tabular}

d) Setelah terbentuk cluster, tahap selanjutnya yaitu memberi nama spesifik untuk menggambarkan isi cluster tersebut, dari ketiga cluster yang terbentuk dapat diklasifikasikan seperti pada Tabel 14.

Cluster pertama : Ke -15 jenis serapan memiliki rata - rata sedang dari cluster kedua dan cluster ketiga, sehingga dapat golongkan menjadi kelompok senyawa dengan serapan absorbansi sedang, anggotanya adalah senyawa 1 dan 4. Cluster kedua : Ke-15 jenis serapan memiliki rata - rata terkecil diantara cluster yang lain, sehingga dapat golongkan menjadi kelompok senyawa dengan serapan rendah, anggotanya adalah senyawa 5. Cluster ketiga : $\mathrm{Ke}-15$ jenis serapan memiliki rata - rata tinggi, sehingga dapat golongkan menjadi kelompok senyawa serapan tinggi, anggotanya adalah senyawa 2, 3, 6, 7 dan 8 .

\section{KESIMPULAN}

Berdasarkan hasil pembahasan, maka dapat disimpulkan bahwa Hasil analisis cluster dari delapan jenis senyawa berdasarkan jenis serapan spektra inframerah, dapat dikelompokkan menjadi tiga cluster, yaitu: cluster pertama adalah kelompok senyawa yang mempunyai serapan sedang (senyawa 1 yaitu fenol dan senyawa4 yaitu fenol:polieugenol, $20: 1$ ), cluster kedua adalah kelompok senyawa yang memiliki serapan rendah (senyawa 5 yaitu fenol : polieugenol, $1: 1$ ), dan cluster ketiga adalah kelompok senyawa yang memiliki serapan tinggi (senyawa 2, 3, 6, 7, dan 8 berturut - turut polieugenol, fenol: polieugenol dengan perbandingan $50: 1,1$ : $2,1: 15$ dan $1: 47$ ).

\section{UCAPAN TERIMAKASIH}

Penghargaan yang setinggi tingginya atas kehadiran Bapak Dr. Dwi Siswanta, M. Eng dan Dr. Nurul Hidayat Aprilita, M. S., pada saat makalah ini dipresentasikan. Terima kasih atas saran dan masukannya untuk perbaikan pada makalah ini.

\section{DAFTAR PUSTAKA}

Budhi, G. S., Liliana dan S. Harryanto, 2008, Cluster Analysis untuk Memprediksi Talenta Pemain Basket Menggunakan Jaringan Saraf Tiruan Self Organizing Maps (SOM), Jurnal Informatika Vol. 9, NO. 1, $23-32$.

Fraley, C. and A. E. Raftery, 2002, ModelBased Clustering, Discriminant Analysis, and Density Estimation, Journal of the American Statistical Association, 97, pp. $611-631$. 
Fraley, C., dan A. E. Raftery, 2007, Model-based Methods of Classification : Using the Mclust Software in Chemometrics, Journal of Statistical Software, Vol. 18, issue 6.

Fraley, C., A. E. Raftery dan R. Wehrens, 2005, Incremental Model-Based Clustering for Large DatasetsWith Small Clusters, Journal of Computational and Graphical Statistics, Volume 14, Number 3, Pages 529 - 546.

Kiswandono, A. A., 2010, Studi Transpor Fenol Menggunakan Membran Cair Polieugenol, Tesis, Universitas Gadjah mada, Yogyakarta.

Kuncoro, M., 2003, Metode Riset Untuk Bisnis dan Ekonomi. Jakarta : Erlangga

Lambert, J. B., H. F. Shurvell, D. A. Lightner, R. G. Cooks, 2001, Organic Structural Spectroscopy, Prentice-Hall, Inc., New Jersey.

Oh, M., dan A. E. Raftery, 2007, ModelBased Clustering With Dissimilarities : A Bayesian Approach, Journal of Computational and Graphical Statistics, Volume 16, Number 3, Pages $559-585$.
Purwaningsih, D. W., 2007, Analisis Cluster Terhadap Tingkat Pencemaran Udara Pada Sektor Industri di Jawa Tengah , Skripsi, universitas Diponogoro, Semarang.

Raftery, A. E. dan N. Dean, 2006, Variable Selection for Model-Based Clustering, Journal of the American Statistical Association March 2006, Vol. 101, No. 473.

Sartono, B., 2003. Analisis Peubah Ganda. Bogor : IPB

Silverstein, Bassler dan Morril, 1984, Penyidikan Spektrometrik Senyawa Organik, edisi 4, Alih bahasa Hartomo, A. J., dan Purba, A. V., Penerbit Erlangga, Jakarta.

Supranto, J., 2000, Teknik Sampling Untuk Survei dan Eksperimen, Edisi Baru. Jakarta : PT. Rineka Cipta.

Udiyani, P. M., 2007, Analisis Cluster Terhadap Radioaktivitas Alam Tapak Reaktor dan Instalasi Nuklir di Pulau Jawa, Prosiding Seminar Nasional ke -13 Teknologi dan Keselamatan PLTN Serta Fasilitas Nuklir. 